\title{
Zong_Figure S5
}

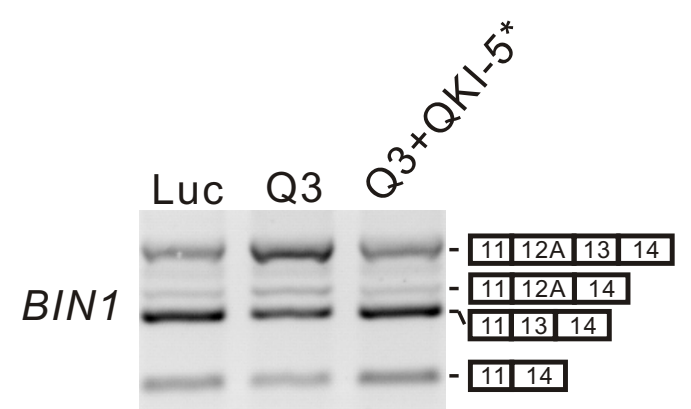

